\title{
Evaluation of Land Use Change in the District Dharmasraya
}

\author{
Edwin $^{\#}$ and Yuzirwan ${ }^{*}$ \\ \# Agroecotechnology Studies Program, Campus III Dharmasraya, Faculty of Agriculture, University of Andalas, Indonesia \\ E-mail: edwin@faperta.unand.ac.id; edwinanas@gmail.com
}

* Soil Department, Faculty of Agriculture, University of Andalas, Indonesia

E-mail: yuzirwanrasyid@yahoo.co.id

\begin{abstract}
Since Dharmasraya Regency, West Sumatra, Indonesia was established in 2004, has an impact on land-use change. Changes in land use can be analyzed quickly through the interpretation of satellite imagery. The methodology used is the analysis of spatial and temporal changes in land use on satellite images captured in 2004, 2009 and 2014 . The result showed that there has been a decline in forest area since Dharmasraya 2004 until 2014. The forest area which was originally in 2004 area is 161.141 ha, in 2009 decreased to 109.056 ha, and in 2014 decreased again to 94.146 ha. This decrease occurred in forest and non-forest areas (areas other use). In 2014, the forest area is available on the forest area is only $22.8 \%$, less than the minimum limit of $30 \%$ in a region. A decrease in forest area is partly due to land clearing for plantations and other uses. Instead of the results of this study also showed that, an increase in area plantation/mixed-garden. In 2004 the area plantation/mixed-garden is 115.831 ha. In 2009 increased to 148.149 ha $(27.9 \%)$ and in 2014 increased to 168.730 ha $(13.89 \%)$. In 2014, the area plantation/mixed-garden in the non-forest area is 142.481 ha $(\mathbf{8 4 . 4 \%})$ and the forest area is $\mathbf{2 6 . 2 4 9}$ ha $(\mathbf{1 5 . 6 \%})$. Supervision required to cope with the increased use of protected areas. This area has been used for plantation / mixed-garden covering an area of 1.127 ha, 816 ha of open land and dry land 17 ha. This area should be restored function into protected forest.
\end{abstract}

Keywords - Land use change; image interpretation; forest and non-forest area

\section{INTRODUCTION}

Dharmasraya district, West Sumatra, Indonesia, established since 2004. The construction of this area is growing rapidly, this is shown by the economic growth in 2013 reached $6.65 \%$. Plantation sector's contribution to Gross Domestic Product (GDP) which is the highest among other sectors, namely $30.83 \%$. [1]. This economic growth has an impact on deforestation. To anticipate the damage to the forest, necessary to control and supervision by the Government, the public and stakeholders. For the purposes of controlling and monitoring data should be available quickly and significantly with coverage. To observe the dynamics of rapid changes in land use cannot be done manually in the field. It is necessary to utilize remote sensing technology and geographic information systems to observe spatially and temporally, more quickly, accurately and efficiently.

To observe the spatial and temporal changes in land use quickly, can be done using remote sensing technology and geographic information systems [2],[3],[4],[5]. Remote sensing is the science and art of obtaining information about an object or phenomenon by analyzing data obtained by using the tool without direct contact with the object, area or phenomenon to be studied [6]. Satellite imagery is one of the results of remote sensing activities. Image interpretation can be done visually or digitally. The principle of visual object recognition in images depends on the characteristics seen on satellite imagery.

Image interpretation can be performed using a geographic information system (GIS). The use of GIS has evolved into a wide range of knowledge that can be integrated with spatial information. Among them is to analyze changes in land use / land cover using satellite imagery spatial data. The Superiority of satellite images from other image is that it can provide spatial data with different levels of sharpness and resolution time dimension. Therefore, the analysis of changes in land use / land cover more appropriate use of satellite imagery data. [4] [6].

Analysis of changes in land use / land cover can be done by creating a matrix of land use change / land cover based on the results of GIS analysis is observed or studied. Matrix of land cover changes can be seen major changes that occur every year. 


\section{MATERIAL AND MethoD}

\section{A. Study Area}

Dharmasraya district is one of the counties that are in West Sumatra is Indonesia, the area is 302.599 hectares. Geographically, the study area is located on $0^{\circ} 47$ '07' South latitude - $1^{\circ} 41^{\prime} 56$ 'south latitude and $101^{\circ} 09^{\prime} 21$ " East Longitude - $101^{\circ} 54$ '27' east longitude [1].

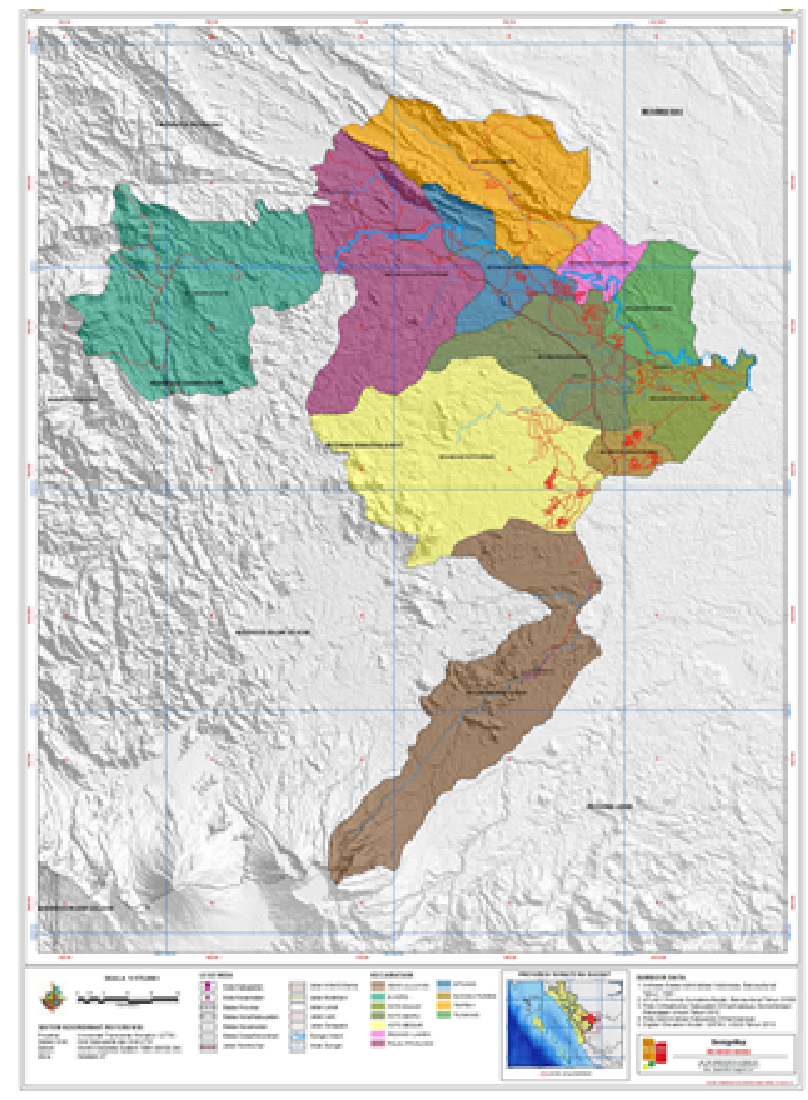

Fig. 1. Map of study sites in the District Dharmasraya

\section{B. Data Sources and Processing}

The data used is a satellite image of Landsat 5 TM (2004), Landsat 7 TM (2009) and Landsat TM 8 (2014) in the form of raster [7]. Visual map of the earth in the form of a vector [8]. Map of administrative boundaries in the form of a vector [9]. Map of forest area in the form of a vector [10].

Satellite image processing using ArcGIS software version 10.1. Geometric correction of satellite imagery aims to improve satellite imagery to match the coordinates of the actual position of the earth. Geometry correction process is done by creating control points (GCP) on satellite imagery with the same point on Earth at some point with reference to the road and the river, for example, at the junction of the road and the river.

After geometric correction on the satellite image, then continued with radiometric correction using ER Mapper 7.0 software. Radiometric correction function to minimize errors caused satellite detectors influence or the influence of atmospheric interference.

\section{Satellite Image Interpretation}

Satellite image interpretation process is the analysis and identification of objects using ArcGIS 10.1 software. This process is done by interpreting the image such as color or the color, shape, size, roughness, pattern, shadow, websites, associations and convergence of evidence. Interpretation and image classification is done by using the supervised classification (supervised classification) with Maximum Likelihood method using a combination of composite band for vegetation analysis of land use. Classification of land use / land cover based on the National Standardization Agency [11] using 6 classes of the dominant land use in Dharmasraya a scale of 1: 50.000, namely; forests, plantations or mixed garden, open land, settlements, fields, and the dry land.

The forest is an ecosystem unity in form of landscape biological resources, dominated by trees in their natural environment, one and the other can not be separated. What is meant by forest in this class is the dry forest, the forest grow and thrive in dry land habitat which may include lowland forests, hills, mountains, high plains or tropical forests. Plantation or mixed garden is a land used for agricultural activities without a change of the plant for two years. Open land is a land without land cover both natural, seminatural or artificial. Settlements are areas or land used as a living environment or residential environment, and activities that support the activities orangKelas fields, rice paddies, the other is the dry land agriculture with the cultivation of temporary or nomadic, including rice paddies, ponds, and others. Dryland is an area of dry land that had been overgrown with a variety of heterogeneous and homogeneous natural vegetation with rare kerapatn level up to the meeting. Regions dominated by low vegetation (natural).

Land use analysis results are validated through field inspections. Then proceed with the digitization process for making land use maps of 2004, 2009, and 2014

\section{Analysis of Land Use Change}

Land use change analysis done by the analysis of data sources, spatial and temporal. Analysis of the data source is done by comparing the analysis of data from digitization, from Dharmasraya In figures [1]' [12]-[18], and the Provincial Forestry Office of West Sumatra [19].

Spatial analysis is done by comparing the total area of land use class in Dharmasraya in the same year. Subsequently be overlaid with forest areas designated by the Minister of Forestry [20] to evaluate changes in the land use class forest and non-forest areas (areas other uses). Temporal analysis is done by evaluating or comparing the change in land use classes in 2004, 2009 and 2014. 


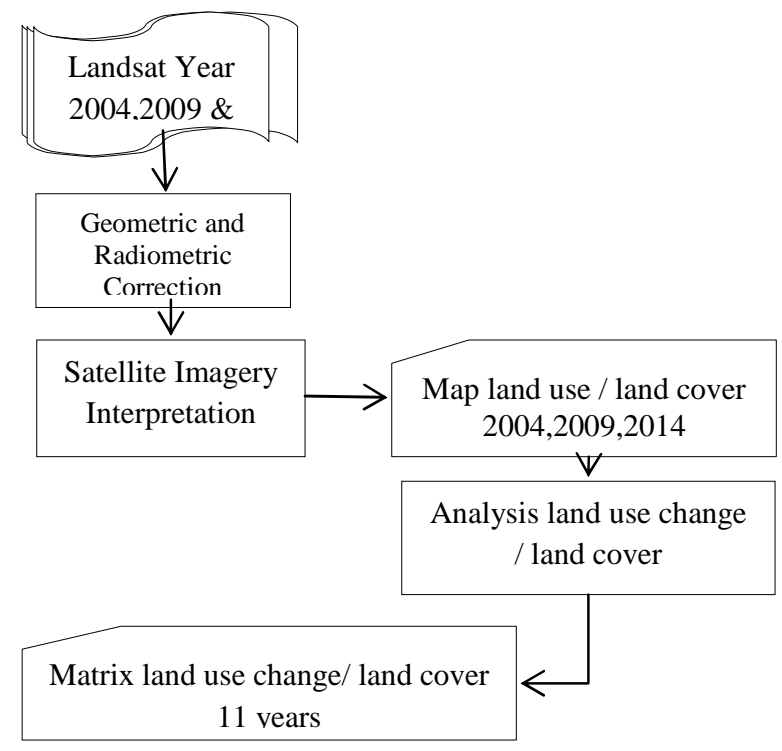

Fig. 2. Stages of data processing and analysis of land use change

\section{RESULT AND ANALYSIS}

\section{A. Result}

Interpretation of land use classes are grouped into the forest, plantation / mixed garden, open land, settlement, farm / field and dry land. Then the results intrepetasi land use map is overlaid with forest and non-forest areas (areas other usage / APL) based on the Ministry of Forestry Republic of Indonesia Number: SK.304 / Menhut-II / 2011 [10],[20].
Based on the results of interpretation/digitization class overlay land use and forest area, then evaluated the spatial and temporal for 2004, 2009 and 2014. The map can be seen in Figure 2.

Data interpretation/ digitization compared to the Central Bureau of Statistics Dharmasraya [12]-[18] and data forested areas of West Sumatra [10],[20].

In Table 2, in general it can be seen that, the availability of secondary data is not complete between 2004 and 2014. This can be seen, from 2004 to 2007 there was no secondary data sourced from the forest areas Book Dharmasraya In Figures. This data is only available in 2008 until 2014. From Table 2, it can also be seen that the total area of Dharmasraya according to according Dharmasraya In Figures 2008-2012 was 296.113 ha and according Dharmasraya In the figure in 2013 was 296.119 hectares. While the results of the measurement map Spatial Planning (Governor of West Sumatra, 2012) is 301.115 ha and the overlay is 299.131 ha. These differences are possible because the boundaries of a district on the field is not yet clear.

Furthermore, from Table I, it can also be seen that the total forest area Dharmasraya according to according Dharmasraya In Figures in 2013 was 92.155 hectares. While the results of the measurement map Spatial Planning [10] is 92.208 ha and the overlay is 100.169 ha. These differences occur because the boundaries are not clear field as well as on the measurement results of the overlay, the body of water is not separated.

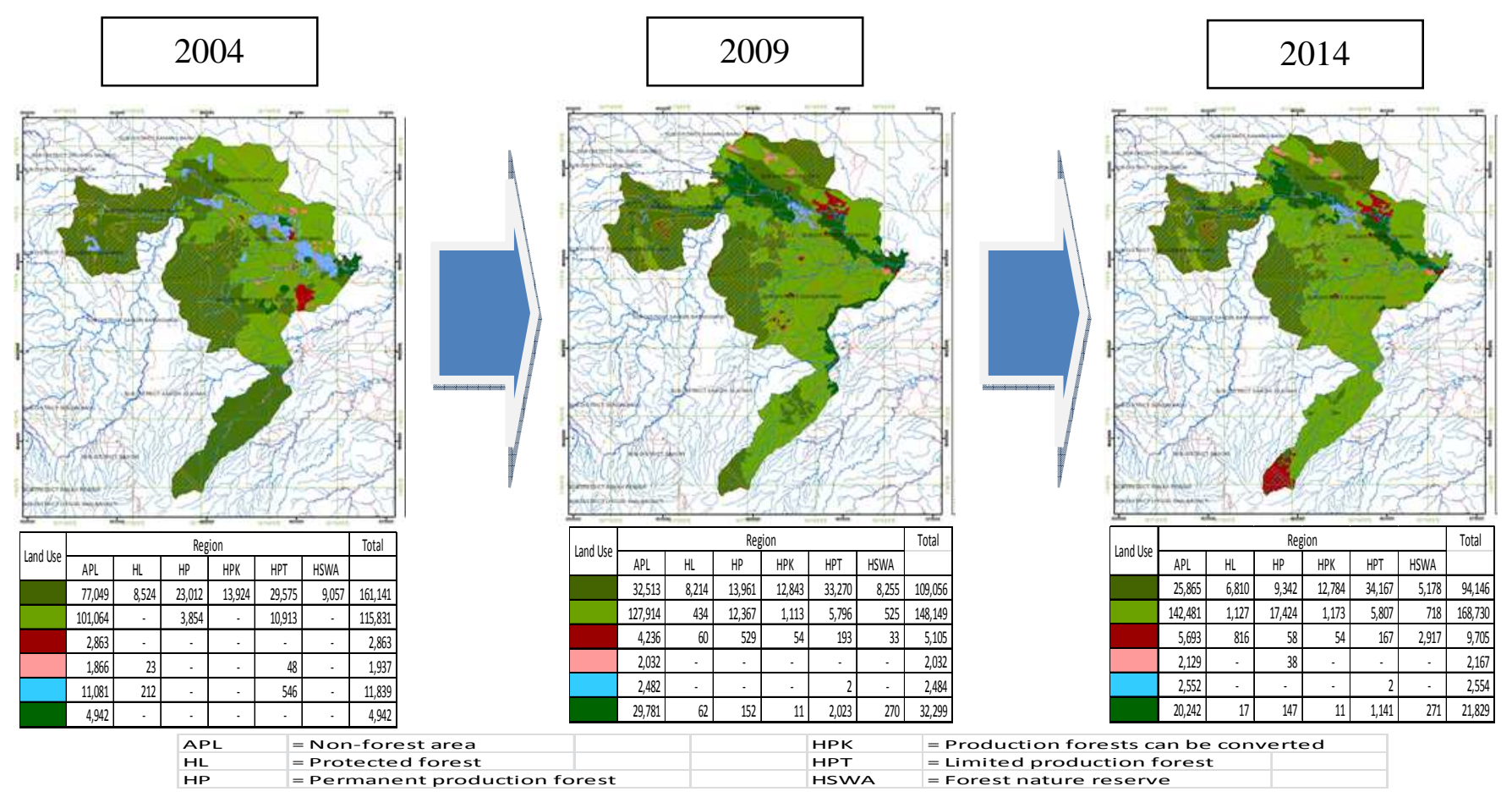

Fig. 3. Map of the results of digitization of land use change in 2004, 2009, 2014 
TABLE I

DATA Forests AND Non-Forest AREAS (AREA OtHER USE) IN THE DHARMASRAYA District (2004-2014)

\begin{tabular}{|c|c|c|c|c|c|c|c|c|c|c|c|c|}
\hline Regional & Data Source & 2004 & 2005 & 2006 & 2007 & 2008 & 2009 & 2010 & 2011 & 2012 & 2013 & 2014 \\
\hline \multirow{3}{*}{ APL } & Digitization & 198,865 & nd & nd & nd & nd & 198,958 & nd & nd & nd & nd & 198,962 \\
\hline & DDA & - & nd & nd & nd & 196,594 & 196,594 & 192,023 & 192,023 & 203,963 & 203,964 & tad \\
\hline & RTRW & - & nd & nd & nd & nd & nd & nd & nd & 208,907 & 208,907 & tad \\
\hline \multirow{3}{*}{$\mathrm{HL}$} & Digitasi & 8,759 & nd & nd & nd & tad & 8,770 & tad & tad & tad & tad & 8,770 \\
\hline & DDA & - & nd & nd & nd & 7,256 & 7,256 & 6,923 & 6,923 & 11,986 & 11,987 & nd \\
\hline & RTRW & - & nd & nd & nd & nd & nd & nd & nd & 11,962 & 11,962 & nd \\
\hline \multirow{3}{*}{ HP } & Digitasi & 26,866 & nd & nd & nd & nd & 27,009 & nd & nd & nd & nd & 27,009 \\
\hline & DDA & - & nd & nd & nd & 24,215 & 24,215 & 38,245 & 38,245 & 26,770 & 26,771 & nd \\
\hline & RTRW & - & nd & nd & nd & nd & nd & nd & nd & 26,692 & 26,692 & nd \\
\hline \multirow{3}{*}{ HPK } & Digitasi & 13,924 & nd & nd & nd & nd & 14,021 & nd & nd & nd & nd & 14,022 \\
\hline & DDA & - & nd & nd & nd & 12,907 & 12,907 & 12,960 & 12,960 & 16,761 & 16,762 & nd \\
\hline & RTRW & - & nd & nd & nd & nd & nd & nd & nd & 16,914 & 16,914 & nd \\
\hline \multirow{3}{*}{ HPT } & Digitasi & 41,082 & nd & nd & $\mathrm{nd}$ & nd & 41,284 & nd & nd & nd & nd & 41,284 \\
\hline & DDA & - & nd & nd & nd & 45,266 & 45,266 & 40,266 & 40,266 & 31,224 & 31,225 & nd \\
\hline & RTRW & - & nd & nd & nd & nd & nd & nd & nd & 31,089 & 31,089 & nd \\
\hline \multirow{3}{*}{ HSWA } & Digitasi & 9,057 & nd & nd & nd & nd & 9,083 & nd & nd & nd & nd & 9,084 \\
\hline & DDA & - & nd & nd & nd & 9,875 & 9,875 & 5,696 & 5,696 & 5,409 & 5,410 & nd \\
\hline & RTRW & - & nd & nd & nd & nd & nd & nd & nd & 5,550 & 5,550 & nd \\
\hline \multirow{3}{*}{ Total } & Digitasi & 298,553 & nd & nd & nd & nd & 299,125 & nd & nd & nd & nd & 299,131 \\
\hline & DDA & - & nd & nd & nd & 296,113 & 296,113 & 296,113 & 296,113 & 296,113 & 296,119 & nd \\
\hline & RTRW & - & nd & nd & nd & nd & nd & nd & nd & 301,115 & 301,115 & nd \\
\hline \multirow[t]{6}{*}{ Keterangan } & : DDA & \multicolumn{3}{|c|}{ = Dharmasraya in Figures } & & & & & & & & \\
\hline & : RTRW & \multicolumn{3}{|c|}{$=$ Regional Spatial Plan } & & & & & & & & \\
\hline & :APL & \multicolumn{2}{|c|}{$=$ Non-forest area } & & HPK & \multicolumn{4}{|c|}{$=$ Production forests can be converted } & & & \\
\hline & $: \mathrm{HL}$ & \multicolumn{2}{|c|}{$=$ Protected forest } & & HPT & \multicolumn{3}{|c|}{$=$ Limited production forest } & & & & \\
\hline & :HP & \multicolumn{3}{|c|}{$=$ Permanent production forest } & HSWA & \multicolumn{2}{|c|}{$=$ Forest nature reserve } & & & & & \\
\hline & : nd & \multicolumn{2}{|c|}{$=$ no data available } & & & & & & & & & \\
\hline
\end{tabular}

\section{B. Analysis}

\section{1) Changes in Land-Use Forest in Forest Regions}

Results of interpretation and digitization of forest land use in Dharmasraya can be seen in Table II, Table III and Figure 4. Overall utilization decreased forest land. In 2004 the area of forest land either area of forest and non-forest area is 161 141 ha. In 2009 increased to 109056 ha in 2014 and increased again to 94.146 ha. According to the Indonesian Government Regulation (President of the Republic of Indonesia, 2008), to realize the function of protected areas in a region of the island with an area of minimum least $30 \%$ (thirty percent) of the area of the island in accordance with the conditions of its ecosystem.

TABLE II.

COMPARISON OF Forest AREA IN THE District DHARMASRAYa IN 2004, 2009 AND 2014

\begin{tabular}{|c|c|c|c|c|c|c|c|}
\hline \multirow{3}{*}{ No } & \multirow{3}{*}{ Region } & \multicolumn{2}{|c|}{2004} & \multicolumn{2}{|c|}{2009} & \multicolumn{2}{|c|}{2014} \\
\hline & & \multicolumn{6}{|c|}{ Forest } \\
\hline & & $\mathrm{Ha}$ & $\%$ & $\mathrm{Ha}$ & $\%$ & $\mathrm{Ha}$ & $\%$ \\
\hline 1 & Non Forest Area (APL) & 77,049 & $25.8 \%$ & 32,513 & $29.8 \%$ & 25,865 & $27.5 \%$ \\
\hline 2 & Forest Area & 84,092 & $28.2 \%$ & 76,543 & $25.6 \%$ & 68,281 & $22.8 \%$ \\
\hline 3 & Total Forest & 161,141 & $54.0 \%$ & 109,056 & $36.5 \%$ & 94,146 & $31.5 \%$ \\
\hline 4 & Total Region & 298,553 & - & 299,125 & & 299,131 & \\
\hline
\end{tabular}

The total area of forest land use in 2004 (161.141 ha) compared with the total area Dharmasraya (298.553 ha) is $54.0 \%$. This data is greater than the government limit is $30 \%$. But if further investigation the total forest area in the forest area (84.092 ha) compared with the total area Dharmasraya (298.553 ha) of data obtained $28.2 \%$. This data is smaller than the government limit.

Furthermore, the total area of forest land use in 2009 (109.056 ha) compared with the total area Dharmasraya
( 299.125 ha) of data obtained $36.5 \%$. This data is still larger than government limits. But if the total forest area in the forest area (76.543 ha) compared with the total area Dharmasraya (299.125 ha) is $25.6 \%$. This data is smaller than the limits set by the Government.

Furthermore, the total area of forest land use in 2014 (94.146 ha) compared with the total area Dharmasraya (299.131 ha) is $31.5 \%$. This data is still larger than government limits. But if the total forest area in the forest area (68.281 ha) compared with the total area Dharmasraya (299.131 ha) is $22.83 \%$. This comparison is smaller than $30 \%$ the limits set by the Government.

From the total area of forest functions, only a limited area of forest function product (HPT) which are relatively slight increase in 2004 is 29.575 ha, in 2009 , is 33.270 ha, and in 2014 is 34.167 ha.

Based on the above data it can be concluded that the condition of the forest in the district of Dharmasraya already entered through the minimum area of forest to function protected areas established by the Government. From the above data, extensive use of forest land is likely to go down since Dharmasraya established on January 7, 2004 until 2014.

\section{2) Changes in Land-Use Plantation/Mixed Garden in} Forest Regions

Results of interpretation and digitization of land use plantation / mixed garden in Dharmasraya can be seen in Table IV and Figure 5. Overall use of plantation / mixed garden increased. In 2004, the plantation area / mixed garden, in the forest regions and not the forest region is 115.831 ha. In 2009 , increased to 148.149 ha and in 2014 increased to 168.730 ha. This is evidenced by the plantation sector's 
contribution to Gross Domestic Product (GDP) which is the highest among other sectors, namely $30.83 \%$ [1].

In the non-forest regions (APL), an increase in plantations/mixed gardens from 2004 - 2014. In 2004 the area is 101.064 ha, in 2009 increased to 127.914 ha and in 2014 increased to 142.481 ha.

TABLE. III

AREA LAND-Use OF Forest In 2004, 2009 AND 2014, In DHARMASRAYA (RESULT OF DIGITIZATION)

\begin{tabular}{|c|c|c|c|c|}
\hline \multirow{3}{*}{ No } & \multirow{3}{*}{ Regions } & 2004 & 2009 & 2014 \\
\hline & & \multicolumn{3}{|c|}{ Forests } \\
\hline & & $\mathrm{Ha}$ & $\mathrm{Ha}$ & $\mathrm{Ha}$ \\
\hline 1 & Non-Forest Area (APL) & 77,049 & 32,513 & 25,865 \\
\hline 2 & Protected forest(HL) & 8,524 & 8,214 & 6,810 \\
\hline 3 & Permanent production forest (HP) & 23,012 & 13,961 & 9,342 \\
\hline 4 & Production forests can be converted (HPK) & 13,924 & 12,843 & 12,784 \\
\hline 5 & Limited production forest (HPT) & 29,575 & 33,270 & 34,167 \\
\hline \multirow[t]{2}{*}{6} & Forest nature reserve (HSWA) & 9,057 & 8,255 & 5,178 \\
\hline & Total & 161,141 & 109,056 & 94,146 \\
\hline
\end{tabular}

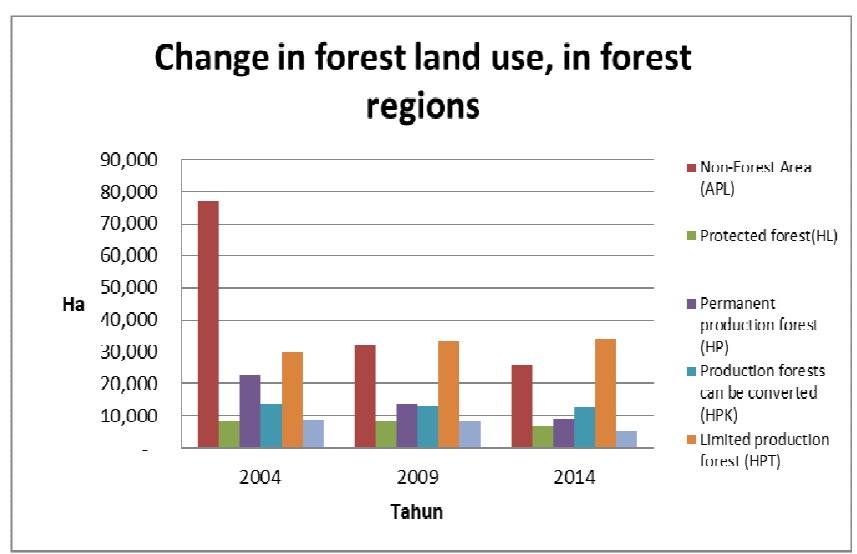

Fig. 4. The graph area of forest land use in 2004, 2009 and 2014, in Dharmasraya (result of digitization)

In the area of permanent production forest (HP), an increase in plantations/mixed gardens from 2004 - 2014. In 2004 the area is 3.854 ha, in 2009 increased to 12.367 ha in 2014 and increased again to 17.424 ha $(10.3 \%)$. This region according to according to the Government of the Republic of Indonesia [21] is set for the principal function of producing forest products. Not intended for plantation. Therefore, permanent production forest area should be the government's attention in order to further improve the supervisory and return to the permanent production forest functions.

In the area of production forest conversion (HPK), an increase in plantations/mixed-gardens from 2004 - 2014. In 2004 there was no plantation / mixed garden, in 2009 increased to $1.113 \mathrm{ha}$, and in 2014 increased to 1.173 ha, The region according to the Minister of Forestry of the Republic of Indonesia [22] is a forest area in the space reserved to be used for development outside forestry. This area could be converted from forest to other uses for existing ones.

In the area of production forest (HPT), the general decline in plantations / gardens mixture from 2004 - 2014. In 2004 is 10.913 ha, in 2009 decreased to 5.796 ha and in 2014 increased to 5.807 ha. This region according to according to the Minister of Forestry of the Republic of Indonesia [22] is a forest area designated for limited production forest reserve forests outside nature. This area is not intended for cultivation areas or other use. Therefore, the Government should improve the supervision and return to function.

At the nature reserve forest area (HSWA), an increase in plantations/mixed-gardens from 2004 - 2014. In 2004 there was no plantation/mixed-gardens. In 2009 increased to 525 hectares and in 2014 increased to 718 ha. This region according to according to the President of the Republic of Indonesia [22], forests with certain characteristics, which has the principal function as a preservation area of plant and animal diversity and the ecosystem, which also serves as an region life support systems. Therefore, the Government should improve the supervision and return to function.

TABLE. IV

AREA Land-Use Of Plantation/MiXed-GaRdEN In 2004, 2009 AND 2014, In DHARMASRAYA (RESULT OF DIGITIZATION)

\begin{tabular}{|c|c|c|c|c|}
\hline \multirow{3}{*}{ No } & \multirow{3}{*}{ Regions } & 2004 & 2009 & 2014 \\
\hline & & \multicolumn{3}{|c|}{ Plantation/Mixed Garden } \\
\hline & & $\mathrm{Ha}$ & $\mathrm{Ha}$ & $\mathrm{Ha}$ \\
\hline 1 & Non-Forest Area (APL) & 101,064 & 127,914 & 142,481 \\
\hline 2 & Protected forest(HL) & - & 434 & 1,127 \\
\hline 3 & Permanent production forest (HP) & 3,854 & 12,367 & 17,424 \\
\hline 4 & Production forests can be converted (HPK) & - & 1,113 & 1,173 \\
\hline 5 & Limited production forest (HPT) & 10,913 & 5,796 & 5,807 \\
\hline \multirow[t]{2}{*}{6} & Forest nature reserve (HSWA) & - & 525 & 718 \\
\hline & Total & 115,831 & 148,149 & 168,730 \\
\hline
\end{tabular}

\section{Changes in Land-Use plantation/mixed garden, in forest regions}

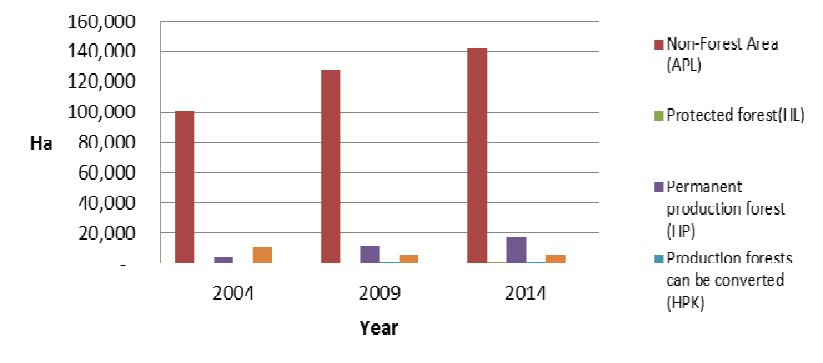

Fig. 5. The graph area of plantation/mixed-garden land use in 2004, 2009 and 2014, in Dharmasraya (result of digitization)

\section{3) Changes in Land-Use Open Land in Forest Regions}

Open land is a land without land cover both natural, seminatural or artificial [11]. Results of interpretation and digitization of open land in the District Dharmasraya can be seen in Table V and Figure 6. Overall open land increased. In 2004 the land area are open to both the area of forest and non-forest area is 2.863 ha. In 2009 rose to 5.105 ha in 2014 and rose again to $9.705 \mathrm{Ha}$. This land is usually the mining land and land left abandoned and covered not the dominant crop.

In 2004, the open land only seen in the non-forest area(other use areas/APL), namely an area of 2,863 ha. In 2009 and 2014, in addition to non-forest areas (APL), have spread also to the forest area. The biggest improvement is in the forest nature reserve (HSWA) covering an area of 2,917 ha and the protected forest area covering an area of 816 ha. In the forest area, activities that occur menyebab open land 
such as mining, is strictly forbidden. But this is still a lot going on in the district of Dharmasraya.

TABLE. V

AREA OF LAND-USE OPEN LAND IN 2004, 2009 AND 2014, IN DHARMASRAYA (RESULT OF DIGITIZATION)

\begin{tabular}{r|rrrr}
\hline \multirow{2}{*}{ No Regions } & \multicolumn{3}{c}{2009} & 2014 \\
\cline { 3 - 5 } & & \multicolumn{3}{c}{ Open Land } \\
\cline { 3 - 5 } & & $\mathrm{Ha}$ & $\mathrm{Ha}$ & \multicolumn{1}{c}{$\mathrm{Ha}$} \\
\hline 1 & Non-Forest Area (APL) & 2,863 & 4,236 & 5,693 \\
\hline 2 & Protected forest(HL) & - & 60 & 816 \\
\hline 3 & Permanent production forest (HP) & - & 529 & 58 \\
\hline 4 & Production forests can be converted (HPK) & - & 54 & 54 \\
\hline 5 & Limited production forest (HPT) & - & 193 & 167 \\
\hline 6 & Forest nature reserve (HSWA) & - & 33 & 2,917 \\
\hline & Total & 2,863 & 5,105 & 9,705 \\
\hline
\end{tabular}

\section{Changes in open land-use, in forest regions}
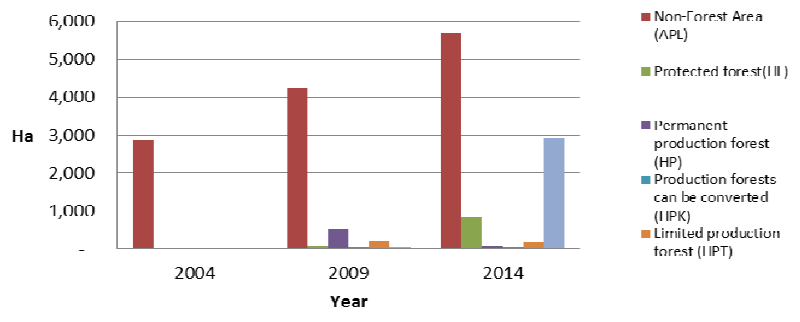

Fig. 6. The graph area of open land in 2004, 2009 and 2014, in Dharmasraya (result of digitization)

\section{4) Changes in Land-Use of Settlement in Forest Regions}

Settlement is an area of land or land used as a living environment or residential environment, and activities that support the activities of the [11]. Results of interpretation and digitization of land settlement in Dharmasraya can be seen in Table VI and Figure 7. Overall settlement land increased. In 2004, both the land settlement area of forest and non-forest area is 1.973 ha. In 2009 meninglkat be 2.032 ha and in 2014 increased to $2.167 \mathrm{Ha}$. Increased settlement is in line with the increasing economic and development Dharmasraya district.

TABLE. VI

AREA OF LAND-USE SETTLEMENT IN 2004, 2009 AND 2014, IN DHARMASRAYA (RESULT OF DIGITIZATION)

\begin{tabular}{|c|c|c|c|c|}
\hline \multirow{3}{*}{ No } & \multirow{3}{*}{ Regions } & 2004 & 2009 & 2014 \\
\hline & & \multicolumn{3}{|c|}{ Settlement } \\
\hline & & $\mathrm{Ha}$ & $\mathrm{Ha}$ & $\mathrm{Ha}$ \\
\hline 1 & Non-Forest Area (APL) & 1,866 & 2,032 & 2,129 \\
\hline 2 & Protected forest(HL) & 23 & - & - \\
\hline 3 & Permanent production forest (HP) & - & - & 38 \\
\hline 4 & Production forests can be converted (HPK) & - & - & - \\
\hline 5 & Limited production forest (HPT) & 48 & - & - \\
\hline \multirow[t]{2}{*}{6} & Forest nature reserve (HSWA) & - & - & - \\
\hline & Total & 1,937 & 2,032 & 2,167 \\
\hline
\end{tabular}

\section{5) Changes in Land-Use of Fields in Forest Regions}

In this interpretation, which is intended to fields (other) are the fields, rice paddies, other. Further defenisinya is is dryland farming with cultivation of temporary or nomadic, including rice paddies, ponds, and others [11]. Results of interpretation and digitization of land use fields (other) in Dharmasraya can be seen from Table VII and Figure 8. Overall fields (other) fluctuations from 2004 until 2014. In 2004 the field (other) in forest areas and non-Forest area is
11.839 ha. Among them there are the protected forest area (HL) 212 ha and the limited production forest (HPT) $546 \mathrm{Ha}$. On land use is dominated by rice paddies and fields. In 2009 decreased to 2.484 ha, caused many people to switch from the field / fields into plantations. In 2014 increased to 2.554 Ha. In general, people still maintain its activities in the plantation business.

\section{Changes in Land-Use Settlement, in forest regions}

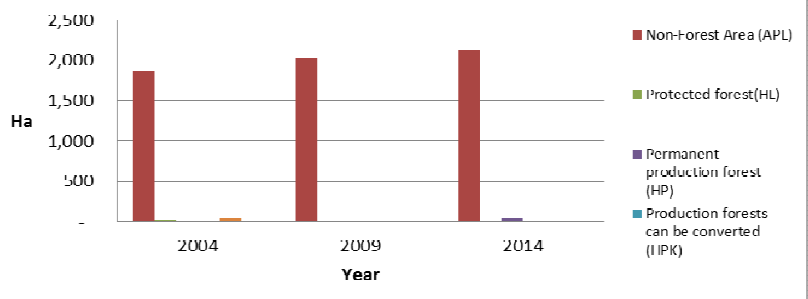

Fig. 7. The graph area of open land in 2004, 2009 and 2014, in Dharmasraya (result of digitization)

\section{TABLE. VII}

AREA OF LAND-USE FIELDS (OTHERS) IN 2004, 2009 AND 2014, IN DHARMASRAYA (RESULT OF DIGITIZATION)

\begin{tabular}{|c|c|c|c|c|}
\hline \multirow{3}{*}{ No } & \multirow{3}{*}{ Regions } & 2004 & 2009 & 2014 \\
\hline & & \multicolumn{3}{|c|}{ Fields } \\
\hline & & $\mathrm{Ha}$ & $\mathrm{Ha}$ & $\mathrm{Ha}$ \\
\hline 1 & Non-Forest Area (APL) & 11,081 & 2,482 & 2,552 \\
\hline 2 & Protected forest(HL) & 212 & - & - \\
\hline 3 & Permanent production forest (HP) & - & - & - \\
\hline 4 & Production forests can be converted (HPK) & - & - & - \\
\hline 5 & Limited production forest (HPT) & 546 & 2 & 2 \\
\hline 6 & Forest nature reserve (HSWA) & - & - & - \\
\hline & Total & 11,839 & 2,484 & 2,554 \\
\hline
\end{tabular}

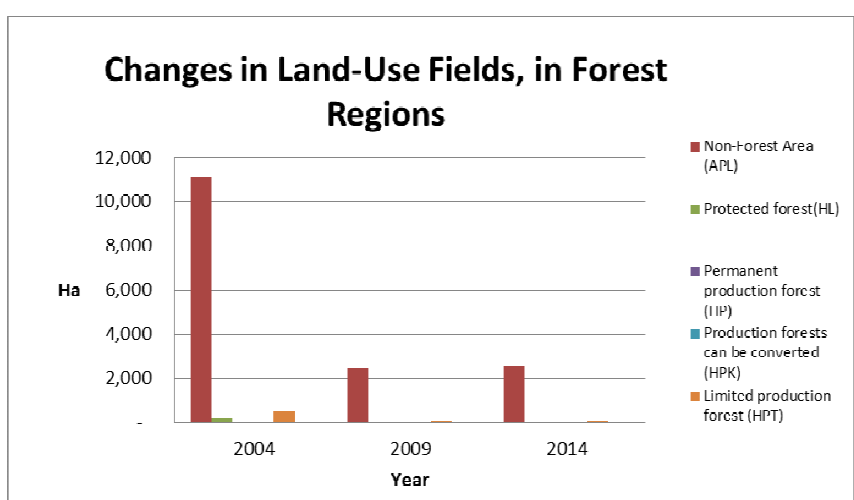

Fig. 8. The graph area of fields (others) in 2004, 2009 and 2014, in Dharmasraya (result of digitization)

\section{6) Changes in Land-Use of dry lands in Forest Regions}

Dryland is an area of dry land that had been overgrown with a variety of natural vegetation heterogeneous and homogeneous with a density that is rarely up to the tightly. Regions dominated by low vegetation (natural) [11].

Results of interpretation and digitization in Dharmasraya district, dry land can be seen in Table VIII and Figure 9. Overall dryland fluctuations from 2004 until 2014. In 2004 the dry land area of the forest area is 4.942 hectares. In the 2009 increased to 32.299 ha, of which in the non-forest area of 29781 ha and the forest area of 2,518 ha. These changes may be caused by clearing forests for plantations, resulting in image interpretation looks like a dry land. In 2014 decreased to 21.829 hectares, of which in the non-forest area 
20.242 ha and 1.587 ha of the forest area. This dry land fluctuations occur due to changes in dry land into other uses quickly occur.

TABLE. VIII

AREA OF LAND-USE DRY LANDS IN 2004, 2009 AND 2014, IN DHARMASRAYA (RESULT OF DIGITIZATION)

\begin{tabular}{rlrrrr}
\hline \multirow{2}{*}{ No Regions } & & \multicolumn{3}{c}{2009} & 2014 \\
\cline { 3 - 5 } & & \multicolumn{3}{c}{ Dry Land } \\
\cline { 3 - 5 } & & \multicolumn{1}{c}{ Ha } & \multicolumn{1}{c}{ Ha } & \multicolumn{1}{c}{ Ha } \\
\hline 1 & Non-Forest Area (APL) & 4,942 & 29,781 & 20,242 \\
\hline 2 & Protected forest(HL) & - & 62 & 17 \\
\hline 3 & Permanent production forest (HP) & - & 152 & 147 \\
\hline 4 & Production forests can be converted (HPK) & - & 11 & 11 \\
\hline 5 & Limited production forest (HPT) & - & 2,023 & 1,141 \\
\hline 6 & Forest nature reserve (HSWA) & - & 270 & 271 \\
\hline & Total & 4,942 & 32,299 & 21,829 \\
\hline
\end{tabular}

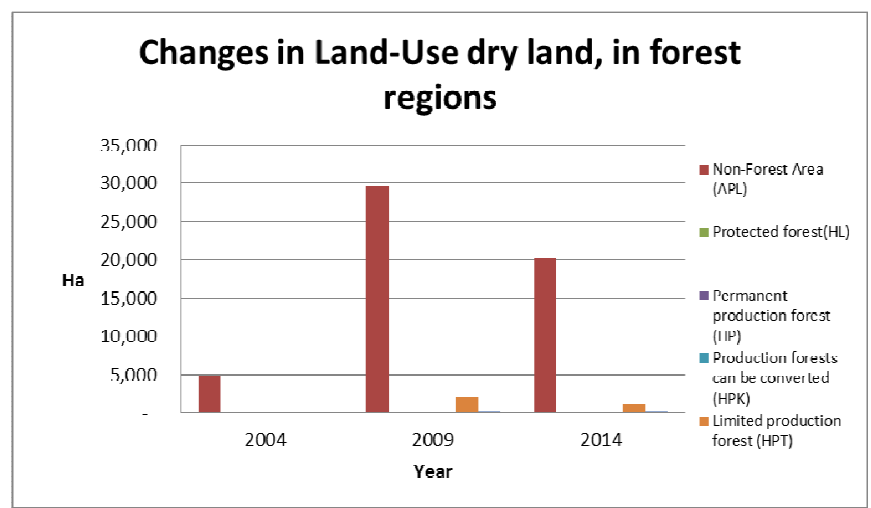

Fig. 9. The graph area of dry lands in 2004, 2009 and 2014, in Dharmasraya (result of digitization)

\section{CONCLUSIONS}

There was a decrease in the use of forest land since Dharmasraya established in 2004, until 2014. The forest area which was originally in 2004 area is 161.141 ha, in 2009 decreased to 109056 ha, and in 2014 decreased again to 94 146 ha. This decrease occurred in forest and non-forest areas (areas other use). In 2014, the forest area is available on the forest area is only $22.8 \%$, less than the minimum limit of $30 \%$ in a region (the President of the Republic of Indonesia, 2008). Supervision required to cope with the increased use of protected areas. This area has been used for plantation / mixed-garden covering an area of 1.127 ha, 816 ha of open land and dry land 17 ha. This area should be restored function into protected forest.

An increase in plantation area Dharmasraya established since 2004 until 2014. In 2004 the plantation area/ mixedgarden is 115831 ha. In 2009 increased to 148.149 ha (27.9\%) and in 2014 increased to 168.730 ha (13.89\%). In 2014 , the plantation/mixed garden area in the non-forest area is 142.481 ha $(84.4 \%)$ and the forest area is 26249 ha (15.6\%).

Overall settlement land increased. In 2004 the settlement land area, area of forest and non-forest area is 1,973 ha. In 2009 increased to 2,032 ha in 2014 , increased again to 2,167 hectares. Increased settlement land is consistent with the growing economy Dharmasraya district.

Overall fields (other) fluctuations from 2004 until 2014. In 2004 the field (other), whether non-forest area and the forest area is 11839 ha. Among them there are the protected forest area (HL) covering an area of 212 ha and the limited production forest (HPT) covering an area of 546 hectares. On land use is dominated by paddy rice and fields. In 2009 decreased to 2.484 ha, caused many people to switch from paddy rice / fields into plantations. In 2014 increased to 2,554 Ha.

\section{REFERENCES}

[1] The Central Bureau of Statistics of Dharmasraya. (2014). Dharmasraya in Figures 2014. Pulau Punjung: BPS- Statistic of Dharmasraya Regency.

[2] Iqbal, M. F., \& Khan, I. A. (2014). Spatiotemporal Land Use Land Cover change analysis and erosion risk mapping of Azad Jammu and Kashmir, Pakistan. 17, 209-229.

[3] Dubovyk, O., Menz, G., Conrad, C., Kan, E., Machwitz, M., \& Khamzina, A. (2013). Spatio-temporal Analyses of Cropland Degradation in the Irrigated Lowlands of Uzbekistan Usingremotesensing and logistic regression modeling. 185, 4775-4790.

[4] Erener, A., Düzgün, S., \& Yalciner, A. C. (2012). Evaluating Land Use/Cover Change with Temporal Satellite Data and Information Systems. 1, 385-389.

[5] Meiyappan, P., Dalton, M., O’Neill, B. C., \& Jain, A. K. (2014). Spatial Modeling of Agricultural Land Use Change at Global Scale. 291, 152-174.

[6] Lillesand, T. M., Kiefer, R. W., \& Chipman, J. (2008). Remote Sensing and Image Interpretation. USA: John Wiley \& Sons Inc, http://www.amazon.com/Remote-Sensing-Interpretation-ThomasLillesand/dp/0470052457\#reader_0470052457.

[7] Indonesian National Institute of Aeronoutics and Space. (2015). Landsat Data. Remote Sensing Technology and Data Centre,

[8] Geospatial Information Agency. (2012). Visual Map of The Earth. Bogor, West Java.

[9] Regional Development Planning Board Dharmasraya. (2015). Map of the Administration Dharmasraya District.

[10] Governor of West Sumatra. (2012). West Sumatra Provincial Regulation No. 13 Year 2012 on Spatial Planning of West Sumatra Year 2012-2032. Padang: Regional Development Planning Board of West Sumatra.

[11] National Standardization Agency (BSN). (2010). Land Cover Classification. Jakarta.

[12] The Central Bureau of Statistics of Dharmasraya. (2007). Dharmasraya in Figures 2007. Pulau Punjung: Development Planning Board of Dharmasraya Regency.

[13] The Central Bureau of Statistics of Dharmasraya. (2008). Dharmasraya in Figures 2008. Pulau Punjung: BPS-Statisct of Dharmasraya Regencey.

[14] The Central Bureau of Statistics of Dharmasraya. (2009). Dharmasraya in Figures 2009. Pulau Punjung: BPS-Statisct of Dharmasraya Regencey.

[15] The Central Bureau of Statistics of Dharmasraya. (2010). Dharmasraya in Figures 2010. Pulau Punjung: BPS-Statisct of Dharmasraya Regencey.

[16] The Central Bureau of Statistics of Dharmasraya. (2011). Dharmasraya in Figures 2011. Pulau Punjung: BPS-Statisct of Dharmasraya Regencey.

[17] The Central Bureau of Statistics of Dharmasraya. (2012). Dharmasraya in Figures 2012. Pulau Punjung: BPS-Statisct of Dharmasraya Regencey.

[18] The Central Bureau of Statistics of Dharmasraya. (2013). Dharmasraya in Figures 2013. Pulau Punjung: BPS-Statisct of Dharmasraya Regencey.

[19] Forestry Agency, West Sumatra Province, Indonesia. (n.d.). Map Forests of West Sumatra Province, Indonesia. Padang, 2014.

[20] Minister of Forestry of the Republic of Indonesia. (2011). Decree of the Minister of Forestry of the Republic of Indonesia Number: SK.304 / Menhut-II / 2011 on Amendment forest areas into nonforest areas covering.

[21] President of the Republic of Indonesia. (1999). Law of the Republic of Indonesia Number 41 Year 1999 on Forestry.

[22] Minister of Forestry of the Republic of Indonesia. (2009, July). Regulation of the Minister of Forestry of the Republic of Indonesia No. P.50 / Menhut-II / 2009 on the affirmation of the status and functioning of Forest Area. 